The 'Promise' of the 1970s: Ratu Mara on the World Stage:

Jack Corbett

State, Society and Governance in Melanesia

School of International, Political \& Strategic Studies

ANU College of Asia \& the Pacific

Australian National University

Canberra ACT 0200

AUSTRALIA

jack.corbett@anu.edu.au

Tel: +61261258394

Fax: +61 261255525

John Connell

School of Geosciences

The University of Sydney

Sydney, NSW 2006

john.connell@sydney.edu.au

A slightly amended version of this paper is published in the journal The Round Table 103(3): 301-310

Acknowledgements: The authors would like to thank Brij V Lal and Deryck Scarr for comments on an earlier version of this paper. Any errors are of course our own. 


\title{
The 'Promise' of the 1970s: Ratu Mara on the World Stage
}

\begin{abstract}
The present era of global governance presents enormous possibilities for small island states due to their sovereign status in international organisations. Despite these apparent advantages asymmetries prevail as human resource constraints pose major obstacles for countries seeking to maximise their influence in global forums. This, however, was not the case in the late 1970s when Pacific leaders were far more assertive in regional and international forums. The most prominent such leader was Ratu Mara, the Prime Minister of Fiji. Examination of his role suggests the unusual nature of the decade of independence for most Pacific island states. This highlights the importance of both broader trends - the global push for self-determination, in the immediate post-colonial era, the particular dynamics of domestic Fijian politics, including Ratu Mara's dominance of the government executive and the administrative support of close aides and his own personal capabilities, specifically his international educational history and chiefly lineage. Four decades later such circumstances no longer exist. Whilst that era provides a powerful illustration of the promise that global governance offers small island states and their leaders, the combination of circumstances that surround Ratu Mara's political tenure simultaneously reaffirm the more general theme of limited influence.
\end{abstract}

Keywords: Small Island States, Ratu Sir Kamisese Mara, Pacific Islands, Fiji, Global Governance 
Small island states in the Pacific are generally portrayed as occupying a precarious place in the world of international affairs, while also being characterised as having a number of now wellknown constraints to development, including small populations, narrow resource bases (including human resources), remoteness, fragmentation, susceptibility to natural hazards (from cyclones to earthquakes), vulnerability to external economic shocks, excessive dependence on aid and imports, and fragile environments. Sovereignty provides opportunities that are not available to similar sized populations, groups and regions in larger countries and yet the costs of maintaining the apparatus of a nation state are onerous and can provide only limited support to island leaders representing their countries in international meetings, forums and assemblies. Recent literature suggests that contemporary political leaders struggle to overcome human resource constraints in these settings, with the greater complexity of a growing number of international organisations, since the relative size and experience of their bureaucratic and political apparatus is a significant limitation which, in extreme cases, makes representation on the world stage an intimidating prospect ([omitted]; Lewis 2005; Grynberg and Joy 2006; McNamara 2009; Wallis 2010; Moore 2011). Consequently, current leaders of small island states often have little real influence in international geopolitics - they may attend and listen but being heard and driving change is difficult.

This pattern, however, is neither uniform, nor has it always been true. The period immediately following the first phase of decolonisation in the Pacific Islands (essentially the decade stretching from the mid-1970s) serves as an important counter case to the contemporary depiction of relative powerlessness and asymmetry. In this article we explore the promise of this period through the life of the region's most prominent postcolonial leader: the inaugural Prime Minister of Fiji, Ratu Sir Kamisese Mara. The example of Ratu Mara is central to any discussion 
about the capacity of leaders from small island states to have an influence on the world stage (even his staunchest opponents concede that he exercised unusual sway) as, even though his Prime Ministership was prior to the new era of global governance, his life story provides a seminal illustration of the potential that a sovereign voice offers islander nations.

In examining some of Ratu Mara's achievements on the world stage we draw out the different factors that underpinned his ability to exert unmatched influence. We do not seek to radically reread the existing body of scholarship on the man and his times (for a fuller account see Mara, 1997; Scarr 2008) - although where necessary we draw out the divergent views of both supporters and detractors - but instead focus on what can be learnt from his actions on the world stage. In turn, this example highlights the extent to which contemporary leaders confront vastly altered terrain. Long gone is the warm and unifying glow of decolonisation that underpinned islander assertiveness and the unity of regional institutions in the late 1970s. In its place is prevailing concern with poor governance, corruption and disunity, both within and between island countries. Similarly, the relatively straightforward nature of intergovernmental relations of that period has been supplanted by a complex network of international organisations, regional bodies and other non-government actors that contemporary leaders find difficult to navigate. Consequently, while this analysis points to the significance of particular leadership qualities through the close examination of one individual in a different geopolitical era - but one that is only forty years distant - it also highlights the very significant changes to the practice of leadership in international affairs for Pacific Islanders since that time. 


\section{Ratu Mara: 'Man of the Century'}

Fijian historian Brij V. Lal (2012: 5) has called Ratu Mara the 'preeminent Fijian political leader of his time' but in many ways his background is typical of the independence generation of Pacific leaders (Corbett, 2012). A high chief by birth - he held the Tui Nayau title (Mara 1997: 91) - Ratu Mara was a man of considerable presence (six foot five inches tall) and ability (Lal 2012: 75). From an early age he was groomed for leadership by his great uncle, Ratu Sir Lala Sukuna, who, with his leadership potential in mind, brought an end to his medical studies at Otago University in New Zealand (after high school in Auckland) by insisting that he attend Oxford to study modern history (Scarr 2008: 46). He later also attended the London School of Economics. On returning to Fiji from his studies he held various positions in the colonial administration. In November 1965 he was a founding member of the Alliance Party and became Fiji's first Prime Minister at independence in 1970. He considered himself to be a 'complete modern Fijian' (Mara 1997: 13) but also a 'citizen-chief' (Scarr 2008: 244), and his life story is often used as an example of the strengths and limitations of combining 'traditional' rulership with 'modern' parliamentary democracy. In this article we focus on the latter.

One of the first instances that marked Ratu Mara out as a force on the world stage was his outspoken attack on the South Pacific Commission (SPC) at the 1965 Conference in Lae (for a summary see Fry 1980: 461-463). SPC was then controlled by representatives of the major nations with territorial interests in the region but from the early 1960s Pacific leaders undertook to challenge this supremacy and the triennial South Pacific Conference, which encouraged the involvement of Pacific Islanders, was the forum through which they did so (Fry 1980: 461).

\footnotetext{
${ }^{1}$ Veteran Pacific journalist Robert Keith-Reid anointed Ratu Mara with this title in his cover report of the December 1999 edition of Island Business, the foremost regional business magazine.
} 
Following a concerted push for greater control at the 1962 meeting in Pago Pago, American Samoa, the Commission decided to grant the Conference increased influence over its work plan. However, delegates at the 1965 Conference in Lae, Papua New Guinea, were disappointed with how these new arrangement worked in practice (Fry 1980:462), with Ratu Mara (1997: 170) later describing his frustration at the 'paternalistic', 'arrogant' and 'autocratic' views of the colonial powers:

The powers seemed incapable of realizing that the winds of change had at last reached the South Pacific and that we peoples of the territories were no longer going to tolerate the domination of the Commission by the Metropolitan powers. We were sick of having little to say and no authority (Mara cited in Fry 1980: 462).

To highlight his displeasures, Mara staged a walkout or "rebellion" with his Pacific colleagues that turned out to be a watershed moment in regional affairs (Fry 1980: 462).

Ratu Mara also played a central role in the formation of several regional institutions. He is most famously synonymous with the early years of the South Pacific Forum - later the Pacific Islands Forum (PIF) - but he earlier established the Pacific Island Producers' Association (PIPA) in 1965. Organised by the same group of leaders present at the Lae meeting (including others of that generation like Albert Henry of Cook Islands and Tupua Tamasese Lealofi IV of Western Samoa) but initiated by Ratu Mara, who was then the Minister for Natural Resources in Fiji, PIPA was designed to foster closer cooperation between island territories supplying bananas to the New Zealand market (Fry 1980: 463). Predominantly a Polynesian venture (other members included the newly independent nation of Western Samoa, the Cook Islands, Niue, Tonga and the Gilbert and Ellice Islands, which later became the independent nations of Kiribati and 
Tuvalu), it later broadened its scope to include other primary products (Fry 1980: 463).

Importantly, it was a considered attempt to foster self-determination in a rapidly decolonising region.

Ratu Mara became Prime Minister of Fiji at independence in 1970 (only the third Pacific state to become independent, after the much smaller states of Western Samoa and Nauru). Ratu Mara's leadership during the early years of the Forum is well known - his famously coined the phrase 'Pacific Way', which stands as a powerful rhetorical imagining of regional identity, whilst his influence over the ensuing decades was such that it provoked an angry reaction from other nations who believed his authority brought undue benefits to Fiji (see Crocombe 2008: 572)and so we will not recover that ground in great detail here. The important point is that building on his prominence in these early regional initiatives, combined with Fiji's strategic geopolitical location as the hub of Pacific regionalism and the fact that it was the sole Pacific Island member of the United Nations from 1970-1975, Ratu Mara gained a reputation in the 1970s as the undisputed leader of the region. As we shall see, this supremacy generated some disquiet amongst the leaders of other island nations, but nonetheless it catapulted Ratu Mara onto the world stage as the spokesperson for Pacific peoples. It is from this position of authority that he was able to make his mark as a founder and chairman of the African Caribbean Pacific Group (ACP) of states (Scarr 2008: 203). He also took the lead in articulating the desire for the Pacific Way, where Pacific island states would both work together and develop more self-reliant policies distinct from those of their colonial powers

The highpoint of Ratu Mara's efforts on the world stage was the ratification of the 1975 Lomé Convention, the predecessor of the 2000 Cotonou Agreement, a key feature of which was non- 
reciprocal trade preferences in European markets for the ACP, and a compensatory mechanism for loss of export earnings due to price fluctuations. The countries which later became ACP members were then concerned that the fledging European Community would safeguard the interests of its members at great cost to the emerging economies of countries like Fiji. Specifically, Fiji sought a guaranteed sugar price for the country's main export industry. In

response, the ACP was formed by the Georgetown Agreement and the first iteration of the Lomé Convention was signed later in the same year. Ratu Mara’s biographer, Scarr (2008: 203), describes how this was achieved:

On the sugar front, Ratu Mara largely settled that issue when, as a founder and current chairman of the African-Caribbean-Pacific Group, he suddenly flew from Brussels to London wearing his Gunner's tie and, in conversation over a bottle of Black Label whisky about every other matter under the sun with Fred Peart, the British Minister for Agriculture who wore the same tie, he got the EEC offer raised. Attaining a guaranteed sugar price was a remarkable success. Ratu Mara himself (1997: 165) claimed that it provided an additional income of $\$ 109$ million from an industry that would have otherwise been badly affected by the fall in the world sugar price from 1975-1980. He also effectively founded the nation's pine timber industry.

\section{Mara in Context: the 'Promise' of the 1970s}

Several lessons can be drawn from Ratu Mara's influence regionally and internationally. In part his story is underpinned by the mood of the time where the promise and hope of post-colonialism and self-determination generated significant goodwill towards newly independent countries - a vastly different attitude from contemporary conditionality arrangements. At the same time this 
also illustrates the manner in which international affairs were conducted in the 1970 s, a significant part of which was the circuit of international forums and assemblies frequented by Prime Ministers and Presidents; 'State receptions, presidential handshakes, guards of honour and the rest became pretty much par for the course' (Scarr 2008: 196).

In contrast to the contemporary situation of intimidation and capacity constraints, one of Ratu Mara's great assets on the world stage was his ability to master this setting and leverage his considerable social capital. He makes several references in his memoirs to the benefits of his Oxford education in particular, recalling, for example, that on meeting Queen Margrethe II of Denmark: 'She had been to Oxford University, and this provided a happy talking ground' while his reflections on the 1971 Commonwealth Heads of Government Meeting (CHOGM) outline how he found himself "very much in sympathy with Sir [Seretse] Khama [of Botswana], who describes himself as “a Queen's man,” and we recalled our meeting at Oxford' (Mara 1997: 189, 47). Throughout his memoir, Ratu Mara emphasises his preference for international meetings conducted in a more informal fashion between leaders and a limited number of officials. In part this relates to the human resource capacity issue - informal settings levelled the playing field for Pacific leaders - while also providing an insight into how he saw his personal strengths as being best exemplified in this setting. He remarked on several occasions (Mara 1997: 148; see also 5657, 79) how he welcomed a proposal by Canadian Prime Minister Pierre Trudeau at CHOGM for informal discussions without advisers:

When I first attended, nearly all the business was formal, and we sat there with a cluster of advisers behind and gave in our names if we wanted to contribute. Prime Minister Trudeau began to break this down ... we met without advisers and could let 
our hair down to discuss the day-today running of government. Because such discussions could be extended to pleasant weekend environments like Gleneagles, the relaxed informality was a further benefit, as well as a chance to get to know colleagues better. It was surprising how many of the problems were similar, irrespective of the size of the country.

His preference for marshalling support in this type of setting perhaps emanates from the 1965 SPC meeting in Lae. However, that meeting was not the only occasion where he lamented the influence of Australia and New Zealand in particular on regional affairs. While his memoir recalls that he argued against then President of Nauru, Hammer de Roburt's wish to exclude these two countries from the Forum on the grounds that they would dominate discussions countering that island economies were too dependent on these countries to exclude them (Mara 1997: 171). However, he later conceded that Forum sessions had lost their gentlemanly atmosphere and had become dominated by Australian and New Zealand bureaucrats:

Australia and New Zealand can dominate the Forum because they have the staff to prepare their case and they come very well briefed. They can talk on practically any subject that comes on the floor, whereas many of us do not have the staff for that, though some of us are helped by long experience (Mara 1997: 174).

Political circumstances were already changing. By contrast, he describes how in early Forum meetings island leaders would meet the night before the main session to align their strategies for dealing with Australia and New Zealand, with each given a part to play in the negotiations:

I was usually detailed to start the arguments on our side. Tu'ipelehake [of Tonga] had to stay out of the argument to the very end. If we were not doing very well, he 
would intervene. Usually he was not very eloquent but he would come down very firmly in a few words, and they would have more respect for him because he sometimes had difficulty in articulating what he wanted to say. Hammer de Roburt's role had been to argue against our arguments, but after Tu'ipelehake talked, Hammer would change, and Albert [Henry, of Cook Islands] would float in and make us laugh ... this procedure went on for four or five years (Mara 1997: 173).

The context of these meetings thus reflected the mood of the times, with regionalism more like a 'gathering of the tribes' or of old school friends: 'We were happy to know each other, renew acquaintances, and recall our roots' (Mara 1997: 18). To a considerable extent leaders had a shared history of colonial education, often with mission support, at home and abroad, a deliberate colonial policy of fostering an elite, and had taken prominent roles in the colonial administration and subsequent decolonisation discussions that led to the establishment of new island nations.

As the 1970s wore on inter-islander relations became more complex, a move that coincided with the decline of Ratu Mara's reputation as undisputed regional leader (Fry 1980: 469). Regional cooperation, initially buoyed by the push for decolonisation and self-determination, was challenged by emerging national concerns, as more island states became independent. The addition of an independent Papua New Guinea to the Forum in 1975 was heralded as a major shift in the balance of regional power away from Ratu Mara and Fiji, despite the inaugural Prime Minister of Papua New Guinea, Sir Michael Somare, adopting a low profile. Indeed, a close relationship between the two nations developed that depended in no small part on the personal friendship between the two leaders (Fry 1980: 473). This changed, however, with Somare's replacement by Sir Julius Chan in 1980. Even before this there was some resentment by other 
island nations at the perceived domination of regional institutions like the University of the South Pacific, Air Pacific, the SPC Community Education Centre and the Telecommunications Training Centre (all of which were located in Fiji) by Fijian interests. For many, Ratu Mara embodied this dominance. Conversely, at home, Ratu Mara also faced pressure from critics who felt his championing of regional programs came at a cost to Fijian interests that had suffered from the compromises and trade-offs of cooperation (Fry 1980: 471). New nations, new institutions and a better informed populace all combined to question Ratu Mara's previously undisputed leadership position.

The promise of the 1970s was steadily eroded and replaced with frustration amongst island communities that development, both domestically and regionally, had not proceeded as planned. It was a view shared by the international development community and its emerging group of international organisations who took a more interventionist stance from that period onwards. In search of better governance, island leaders, like their colleagues from around the world, were cast as problems by the international community; rather than champions of self-determination they became something to be solved by institutional reforms and free market instruments - the tables had turned.

\section{Legacy, Nostalgia and the New Era of Global Governance}

Ratu Mara's supporters and his critics would largely endorse this picture of influence, but his legacy remains heavily contested (Lal 2010, 2012; Scarr 2010). His enthusiasts see a man of incredible intellect, charisma and character who held together a deeply divided country for over a decade. His critics, while acknowledging his centrality, point to several factors in the broader socio-political context, rather than his personal virtues, to explain his impact. Firstly, as outlined 
above, his achievements occurred in the context of Fiji's position, as one of the largest Pacific states at the centre of the region, and at the centre of both British colonial rule until the late 1950s (the Western Pacific High Commissions) and later regional institutions, and the prevailing anti-colonial sentiment of the time which cast independence leaders as heroes of selfdetermination. He was well educated in both 'traditional' and 'modern' ways. When combined with his stature as a high chief and inaugural Prime Minister, Ratu Mara's suitability as a leader was largely unquestioned for much of the 1970s. Ultimately, no other Pacific leader has enjoyed these considerable advantages.

Secondly, he was fortunate to have highly competent support from the civil service, including from his close advisor, Sir Robert Sanders, who might be credited with some of his successes (Lal 2012: 80,3). This is particularly pertinent in terms of human resource capacity issues, especially as Fiji has arguably always had the deepest pool of talented civil servants of all Pacific island states. As global governance became increasingly complicated reliance on technical advisers increased. Consequently, while the combination of able support spearheaded by Sanders' and Ratu Mara's personal charisma and ability was effective in the early 1970s, it is questionable as to whether such a team would be capable of exerting the same influence in subsequent decades. The landscape of global governance and its labyrinth of organisations and experts has been fundamentally altered in a manner that means it is no longer the exclusive domain of well-mannered gentlemen with respectable connections, and committed colonial advisers.

Thirdly, for much of this period Ratu Mara was both prime minister and minister responsible for the foreign affairs portfolio. Holding multiple portfolios is not uncommon in small island states 
where, due to the relative size of parliament, individuals often undertake several roles that are usually distinct in larger states. Based on this centralised authority Ratu Mara could exercise unusual influence on the world stage through his personal control of multiple governing functions. However, his administrative style grated with his critics, one of whom was then High Commissioner to Fiji, H.W. Bullock who describes him as having an inflated sense of his own indispensability which resulted in him controlling nearly all aspects of government administration - causing long delays, especially when his attention was focused on foreign relations (Lal 2012: 80). Whether this is exaggerated or not, contemporary governance is much more complex and centralised and authoritarian leadership would generate even more of the congestion that was then beginning to then occur.

The example of Ratu Mara embodies all the possibilities that sovereignty offers small island states while illustrating the endemic problems. Ratu Mara was considered urbane, sophisticated, and comfortable in a range of settings - from cocktail parties to international meetings - and was held up as the paragon of a statesman prised in the practice of international affairs. Yet this influence was partly contingent on the mood of the time, his undisputed control over nearly all aspects of Fijian politics (his memoir The Pacific Way (1997) is replete with admiration for Singapore's Lee Kuan Yew), secure tenure in office, valuable personal advice, including from Sir Robert Sanders, and support from metropolitan Pacific rim governments who recognised a leader in their own mould.

Regionally Ratu Mara was well supported by a cohort of other post-independence leaders (Hammer de Roburt, Sir Albert Henry, Sir Michael Somare, Sir Robert Rex, Walter Lini and others) who constituted an informal, influential, educated and relatively stable and prestigious 
group. With the exception of Western Samoa, the first Pacific nation to gain independence, no Pacific Island country experienced a leadership change until 1976 (Fry 1980: 469). This is simply unprecedented today where, again with the exception of Samoa and also Kiribati, regular changes of government are common. The presidency of Nauru, for example, changed nine times during the 1990s and five times in 2003 alone while Tuvalu had seven different governments between 1998 and 2006 (Connell 2006; Panapa and Fraenkel 2008). In contemporary Melanesia, where coalition government encourages the proliferation of ministerial portfolios, the regular churn of ministers and the decentralisation of power mean that leaders are rarely granted anything approaching security of tenure.

More generally, the requirements of leadership and governance have grown. Pacific Island countries are now members of numerous international organisations and regional institutions, with a plethora of obligations, meetings and consultative mechanisms. Indeed, as global governance has become more complex the frailties and vulnerability of small island states, in terms of human resources, have increasingly been exposed. International forums are increasingly highly technical arenas and leaders rely heavily on the advice of officials for analysis. However small states 'generally lack the financial and human resources to properly staff and fund the required embassies and missions' (Laurent 2011:219), so affecting their ability to negotiate and be aware of international trends. Complex international negotiations require complex technical knowledge, yet skilled human resources are scarce, and recruitment, development and retention of high quality officials are perpetual challenges. Governance is far beyond the competence of even the most skilled and dedicated individual. 
The achievements of Ratu Mara must therefore be put in the context of both a particular postcolonial era (characterised by good will to new nations, trade opportunities in a more benign global political economy, new infrastructure, independent parliaments and a spirit of postcolonial optimism) and the unusual history of one remarkable talented and well-supported individual, thus indirectly pointing to a present environment where such circumstances are unlikely to reoccur. By default, while illustrating the promise that global governance offers small island states, the setting that frames Ratu Mara's political leadership simultaneously reaffirms the more general theme of limited influence. That is not to be overly nostalgic for a simpler time - Ratu Mara had his critics who were more than happy to see his star fade - nor is it to imply that all contemporary Pacific leaders are bereft of influence on the world stage (President Anote Tong of Kiribati is a prominent spokesperson in global climate talks for example). However, asymmetry remains and while the Ratu Mara example exemplifies the ability of some individuals to substantially influence both national and international affairs, in many respects it is the proverbial exception that proves the general rule.

\section{References}

Connell, J (2006) Nauru: The First Failed Pacific State? The Round Table 95(383), pp. 47-63.

Corbett, J (2012) 'Two Worlds?' Interpreting Leadership Narratives in the 20th Century Pacific, Journal of Pacific History 47(1), pp. 69-91.

Crocombe, R (2008). The South Pacific. 7th Edition. IPS Publications, University of the South Pacific, Suva, Fiji:

Fry, G (1980) Regionalism and International Politics of the South Pacific, Pacific Affairs 54(3), pp. 455-484.

Grynberg, R. and R. M. Joy (2006) The accession of Vanuatu to the WTO: lessons for the multilateral trading system, in R. Grynberg (ed), WTO at the Margins: Small States and the Multilateral Trading System, Cambridge, Cambridge University Press, pp. 693-714. 
Lal, BV (2012) Fiji: The Autocratic Style of Ratu Mara, Archifacts, October, pp. 74-86.

Lal, BV (2010) 'Tuimacilai: A Review Essay', Pacific Currents: The eJournal of the Australian Association for the Advancement of Pacific Studies, no. 1.2 and 2.1.

Laurent, E (2011), 'Priorities for small states in global trade governance', in C Deere Birkbeck (Ed.) Making Global Trade Governance Work for Development, Cambridge University Press, Cambridge, pp. 204-30.

Lewis, P. (2005). 'Unequal Negotiations: Small States in the New Global Economy.' Journal of Eastern Caribbean Studies, 30(1), pp. 54-107.

Mara, K (1997), The Pacific Way, University of Hawaii Press, Honolulu.

McNamara, K. (2009) Voices from the margins: Pacific ambassadors and the geopolitics of marginality at the United Nations, Asia Pacific Viewpoint, 50, 1-12.

Moore, M. (2011). 'Globalisation and Power in Weak States.' Third World Quarterly, 32, 1757-1776.

Panapa, P and J Fraenkel (2008) The Loneliness of the Pro-Government Backbencher and the Precariousness of Simple Majority Rule in Tuvalu, ANU State, Society and Governance in Melanesia Discussion Paper No.2, Canberra.

Scarr, D (2010) 'Where did all the flowers go? A rejoinder to Lal's tirade against Tuimacilai and its ever-mischievous author', Pacific Currents: The eJournal of the Australian Association for the Advancement of Pacific Studies, no. 1.2 and 2.1.

Scarr, D (2008), Tuimacilai: A Life of Ratu Sir Kamisese Mara, Crawford House Publishing, Adelaide.

Wallis, J. (2010). 'Friendly islands' in an unfriendly system: Examining the process of Tonga's WTO accession, Asia Pacific Viewpoint, 51: pp. 262-277. 